\title{
Redox Control of Antioxidant and Antihepatotoxic Activities of Cassia surattensis Seed Extract against Paracetamol Intoxication in Mice: In Vitro and In Vivo Studies of Herbal Green Antioxidant
}

\author{
U. Seeta Uthaya Kumar, ${ }^{1}$ Yeng Chen, ${ }^{2}$ Jagat R. Kanwar, ${ }^{3}$ and Sreenivasan Sasidharan' \\ ${ }^{1}$ Institute for Research in Molecular Medicine (INFORMM), Universiti Sains Malaysia (USM), 11800 Pulau Pinang, Malaysia \\ ${ }^{2}$ Dental Research \& Training Unit and Oral Cancer Research and Coordinating Centre (OCRCC), Faculty of Dentistry, \\ University of Malaya, 50603 Kuala Lumpur, Malaysia \\ ${ }^{3}$ Nanomedicine-Laboratory of Immunology and Molecular Biomedical Research, Centre for Molecular and Medical Research, \\ School of Medicine, Faculty of Health, Deakin University, Geelong, VIC 3216, Australia \\ Correspondence should be addressed to Sreenivasan Sasidharan; srisasidharan@yahoo.com
}

Received 22 June 2016; Revised 29 September 2016; Accepted 19 October 2016

Academic Editor: Ruchi Shah

Copyright (C) 2016 U. Seeta Uthaya Kumar et al. This is an open access article distributed under the Creative Commons Attribution License, which permits unrestricted use, distribution, and reproduction in any medium, provided the original work is properly cited.

\begin{abstract}
The therapeutic potential of Cassia surattensis in reducing free radical-induced oxidative stress and inflammation particularly in hepatic diseases was evaluated in this study. The polyphenol rich C. surattensis seed extract showed good in vitro antioxidant. $C$. surattensis seed extract contained total phenolic content of $100.99 \mathrm{mg}$ GAE/g dry weight and there was a positive correlation $(r>$ $0.9)$ between total phenolic content and the antioxidant activities of the seed extract. C. surattensis seed extract significantly $(p<$ 0.05 ) reduced the elevated levels of serum liver enzymes (ALT, AST, and ALP) and relative liver weight in paracetamol-induced liver hepatotoxicity in mice. Moreover, the extract significantly $(p<0.05)$ enhanced the antioxidant enzymes and glutathione (GSH) contents in the liver tissues, which led to decrease of malondialdehyde (MDA) level. The histopathological examination showed the liver protective effect of $C$. surattensis seed extract against paracetamol-induced histoarchitectural alterations by maximum recovery in the histoarchitecture of the liver tissue. Furthermore, histopathological observations correspondingly supported the biochemical assay outcome, that is, the significant reduction in elevated levels of serum liver enzymes. In conclusion, C. surattensis seed extract enhanced the in vivo antioxidant status and showed antihepatotoxic activities, which is probably due to the presence of phenolic compounds.
\end{abstract}

\section{Introduction}

There is currently much interest in the therapeutic potential of traditional and herbal therapy as an antioxidants in reducing free radical-induced oxidative stress and inflammation particularly in hepatic diseases [1]. The liver is the primary site for metabolism of almost all drugs because it is relatively rich in a large variety of metabolizing enzymes. Drug induced liver injury (DILI) is one of the most frequent causes of liver injury that poses a major clinical problem and challenge to drug regulators [2]. Drug induced liver injury makes up a total of $5 \%$ of all hospital admissions and $50 \%$ of all acute liver failures [3]. Paracetamol-induced hepatotoxicity has been linked with a number of cirrhosis, hepatitis, and suicide attempts cases. Paracetamol, if taken in overdose, can cause severe hepatotoxicity that leads to liver failure and nephrotoxicity depletion [4]. The toxic dose of acetaminophen caused the depletion of total glutathione (GSH) by as much as 90 percent, leading to accumulation of toxic metabolite $\mathrm{N}$-acetyl-p-benzoquinone imine (NAPQI) which then covalently binds to cysteinyl sulfhydryl groups in hepatic protein through the 3-position of the benzene ring, forming NAPQI-protein adducts [57]. 
This causes the generation of ROS such as hydrogen peroxide $\left(\mathrm{H}_{2} \mathrm{O}_{2}\right)$ and hydroxyl $\left(\mathrm{OH}^{-}\right)$radicals that affect the cellular membrane and induce lipid peroxidation by eliminating hydrogen from a polyunsaturated fatty acid and subsequent liver damage or necrosis [8-10]. The toxic metabolite formation and protein binding also cause the dysfunction of mitochondria that leads to adenosine triphosphate (ATP) depletion and oxidant stress [11, 12]. Moreover, numerous mitochondria are found in human liver cells, with about 1000-2000 mitochondria per cell, making up 1/5 of the cell volume [13]. Given the role of mitochondria as the cell's powerhouse, there may be some leakage of the highenergy electrons in the respiratory chain to form reactive oxygen species. This was thought to result in significant oxidative stress in the mitochondria with high mutation rates of mitochondrial DNA (mtDNA) [14]. A vicious cycle was thought to occur, as oxidative stress leads to mitochondrial DNA mutations, which can lead to enzymatic abnormalities and further oxidative stress. Therefore, liver cells with numerous mitochondria are found more vulnerable to free radical oxidation than any other cells in the body. Hence, medicinal plants with hepatoprotective activity are likely to make a considerable contribution for the liver protection against the paracetamol toxicity.

Medicinal plants are an important source of natural antioxidant agents because of the less toxic nature and being free from side effects compared to synthetic antioxidant [15, 16]. Most of these medicinal plants are rich in polyphenol which have the ability to scavenge-free radicals which are generated endogenously [17]. Polyphenols are not synthesized by human being and present only in plants and some microorganisms. Various studies exposed the antioxidant properties of polyphenols towards human pathologies [18]. Cassia surattensis is one of the medicinal plants that is rich in polyphenol with health benefits. The genus Cassia is well known for its diverse biological and pharmacological properties, comprises about 600 species, and is vastly distributed worldwide [19]. The genus Cassia has been used as a potential medicinal plant since long ago [20,21]. C. surattensis belongs to the family Fabaceae, distributed throughout Malaysia, and is widely grown as ornamental plants in tropical and subtropical areas. This plant species has been traditionally used in many countries as food products and for medicinal uses. The bark and leaves of $C$. surattensis are said to be antiblenorrhagic [22]. The decoction of the roots [23] is commonly used to treat snake bites. The leaves are consumed for cough and sore throat and used for both internal and external cooling medicine. C. surattensis flowers and leaves have been studied extensively and the therapeutic properties such as antioxidant [24], antimicrobial [25], and antidiabetic [26] have been reported. According to Deepak et al. [27], C. surattensis seed showed good antioxidant, antifungal, and antibacterial activities on bacterial and fungal cultures. A finding by El-Sawi and Sleem [28] indicated the efficacy of C. surattensis leaf extract as hepatoprotective agent in $\mathrm{CCl}_{4}{ }^{-}$ induced albino rats. Hence, present study is focused on redox control of antioxidant and antihepatotoxic activities of Cassia surattensis seed extract against paracetamol intoxication in mice. The outcome from this work may add to the overall therapeutic value of traditional and herbal medicine in hepatic diseases.

\section{Materials and Methods}

2.1. Plant Sample Collection. The matured pods of C. surattensis were collected from Universiti Sains Malaysia (USM), Pulau Pinang, Malaysia. The C. surattensis plant (leaves with flowers and pods) was authenticated by a botanist at the Herbarium of the School of Biological Sciences, Universiti Sains Malaysia, where a sample with voucher number 11464 has been deposited. The seeds were removed from the pods and were washed under running tap water to remove dirt prior to the drying process. The seeds were dried in an oven at $50^{\circ} \mathrm{C}$. Then, the dried seeds were ground into powder and stored in airtight bottles.

2.2. Preparation of Plant Seed Extract. The powdered seeds $(150 \mathrm{~g})$ were soaked in methanol $(500 \mathrm{~mL})$ for 7 days under room temperature, $28^{\circ} \mathrm{C}$ [29]. The whole extract was filtered and methanol was evaporated from the filtrate by a rotary evaporator (Buchi, Switzerland) at $40-50^{\circ} \mathrm{C}$ to form a paste. Then, the extract was dried in the oven at $60^{\circ} \mathrm{C}$ to get a thick paste form. The crude extract was sealed in Petri plate and stored at room temperature, $28^{\circ} \mathrm{C}$.

2.3. Total Phenolic Content. The total phenolic content of the extracts was determined using the method described by $\mathrm{Li}$ et al. [30]. One $\mathrm{mL}$ diluted Folin-Ciocalteau reagent was added to $1 \mathrm{~mL}$ of methanolic seed extract. Then, $4 \mathrm{~mL}$ sodium carbonate and $10 \mathrm{~mL}$ distilled water were added to the mixture. Subsequently, the mixture was allowed to stand 2 hours at room temperature, $28^{\circ} \mathrm{C}$. The contents were centrifuged and absorbance was measured at $765 \mathrm{~nm}$. The samples were prepared in triplicate for each analysis and the mean value of absorbance was obtained. The same procedure was repeated using various concentrations of gallic acid and a standard curve was constructed. Based on the measured absorbance, the concentration of phenolics was read $(\mathrm{mg} / \mathrm{mL})$ from the standard curve and the total phenolic contents of the extract were expressed as milligrams of gallic acid equivalents (GAE) per gram dry weight ( $\mathrm{mg} \mathrm{GAE} / \mathrm{g} \mathrm{dw}$ ).

\subsection{In Vitro Antioxidant Activity}

2.4.1. Inhibition of 2,2-Diphenyl-1-picrylhydrazyl (DPPH) Radical Scavenging Assay. The DPPH radical scavenging activity of C. surattensis seed methanolic extract was carried out by previously described method by Sangetha et al. [24]. Five $\mathrm{mL}$ of a $0.004 \%(\mathrm{w} / \mathrm{v})$ solution of DPPH in $80 \%$ methanol was added to $50 \mu \mathrm{L}$ of methanolic seed extract at different concentrations $(0.078,0.16,0.31,0.63,1.25,2.50,5.00$, and $10.00 \mathrm{mg} / \mathrm{mL}$ resp.). The reaction mixture was shaken vigorously. Butylated hydroxytoluene (BHT, Sigma) was used as a reference standard. The discoloration of DPPH was measured at $517 \mathrm{~nm}$ after 30 minutes incubation in the dark. The lower absorbance of the reaction mixture indicated higher free 
radical scavenging activity. All the tests were performed in triplicate.

The percentage DPPH radical scavenging was calculated using the following equation:

$$
\% \mathrm{DPPH} \text { radical scavenging }=\frac{A_{o}-A_{1}}{A_{o}} \times 100,
$$

where $A_{o}$ is the absorbance of the control and $A_{1}$ is the absorbance in the presence of the extract/standard.

2.4.2. Inhibition of Nitric Oxide Radical Scavenging Assay. The assay was conducted based on the modification method by Chakraborthy [31]. The reaction mixture contained $1.5 \mathrm{~mL}$ sodium nitroprusside $(10 \mathrm{mM})$ in phosphate buffer saline $\mathrm{pH}$ 7.4 and $0.5 \mathrm{~mL}$ of the seed extract at various concentrations $(1.95,3.91,7.81,15.63,31.25,62.50,125.00,250.00,500.00$, and $1000.00 \mu \mathrm{g} / \mathrm{mL}$ ) and incubated for 150 minutes at $25^{\circ} \mathrm{C}$. Then, $1 \mathrm{~mL}$ of Griess reagent ( $1 \%$ sulphanilamide, $0.1 \%$ naphthylethylenediamine dichloride and 3\% phosphoric acid) was added and the mixture was incubated for 30 minutes at room temperature, $28^{\circ} \mathrm{C}$. The pink chromophore formed during diazotization of nitrite ions with sulphanilamide and subsequent coupling with naphthylethylenediamine dichloride was measured at $546 \mathrm{~nm}$. The activity of seed extract was compared with ascorbic acid which was used as a reference standard. All tests were performed in triplicate. The nitric oxide radicals scavenging activity were calculated according to the equation:

$$
\% \text { Inhibition }=\frac{A_{o}-A_{1}}{A_{o}} \times 100 \%,
$$

where $A_{o}$ is the absorbance of the control and $A_{1}$ is the absorbance in the presence of the extract/standard.

2.4.3. Reducing Power Assay. The reducing power assay was evaluated by the method of Oyaizu (1986) as described by Yildirim et al. [32]. One $\mathrm{mL}$ seed extract at various concentrations $(0.02,0.039,0.078,0.16,0.31,0.63,1.25,2.50$, 5.00 , and $10.00 \mathrm{mg} / \mathrm{mL}$ ) was mixed with $2.5 \mathrm{~mL}$ phosphate buffer (0.2 M, pH 6.6) and $2.5 \mathrm{~mL}$ potassium ferricyanide $[\mathrm{K} 3 \mathrm{Fe}(\mathrm{CN}) 6](1 \% \mathrm{w} / \mathrm{v})$. The mixture was incubated at $50^{\circ} \mathrm{C}$ for 20 minutes in a water bath. The reaction was stopped by adding $2.5 \mathrm{~mL}$ of trichloroacetic acid (TCA) solution $(10 \% \mathrm{w} / \mathrm{v})$ to the mixture and then centrifuged at $3000 \mathrm{rpm}$ for 10 minutes. Then, $2.5 \mathrm{~mL}$ of the upper layer solution was mixed with $2.5 \mathrm{~mL}$ distilled water and $0.5 \mathrm{~mL}$ Ferric chloride solution $(0.1 \% \mathrm{w} / \mathrm{v})$. The reaction mixture was then incubated for 10 minutes at room temperature. Absorbance of the resultant mixture was measured at $700 \mathrm{~nm}$. The increased absorbance of the reaction mixture indicated enhanced reducing power. Ascorbic acid was used as a reference standard.

2.4.4. Calculation of Inhibition Concentration $\left(I C_{50}\right)$. The $\mathrm{IC}_{50}$ is defined as the concentration of the sample that provides inhibition of $50 \%$ of the initial radical concentration with the unit, $\mathrm{mg} / \mathrm{mL}$ or $\mu \mathrm{g} / \mathrm{mL}$. The $\mathrm{IC}_{50}$ values were calculated from the linear regression plots of various concentrations of methanolic extract of $C$. surattensis seed/reference standard against the mean percentage of $\%$ inhibition obtained from three replicate tests.

\subsection{In Vivo Antihepatotoxic Activities}

2.5.1. Animals. Fifteen adult male Swiss albino mice aged 6 to 8 weeks old and weighed 25 to $30 \mathrm{~g}$ were used to study the hepatoprotective activity of C. surattensis seed extract. The Animal Ethics Committee, Universiti Sains Malaysia, has approved the animal study for this project (USM/Animal Ethics Approval/2013/(90)(514)). The animals were kept under standard conditions $\left(27 \pm 2^{\circ} \mathrm{C}\right.$, relative humidity $44-$ $56 \%$ and light and dark cycles of 10 hours and 14 hours, resp.) and fed with standard mice diet and purified drinking water ad libitum for 1 week before and during the experiments. The animals were obtained from Animal house of Universiti Sains Malaysia, Penang, and kept in cages under uniform husbandry condition, standard animal diet, and drinking water ad libitum. The food was withdrawn 18-24 hours before starting the experiment. All experiments were performed in the morning according to current guidelines for the care of the laboratory animals and the ethical guidelines for the investigation of experimental pain in conscious animals [33].

2.5.2. Preparation of Paracetamol Dose Regimen and Treatments. The paracetamol tablets were obtained from a nearby pharmacy. Each tablet contains $500 \mathrm{mg}$ of paracetamol. The mice were administered with paracetamol at a dose of $1 \mathrm{~g} / \mathrm{kg}$ body weight (b.w.). The paracetamol was made into fine powder using a mortar and pestle. The powdered paracetamol was suspended in distilled water and was administered according to the body weight of mice. An aqueous suspension of seed extract was prepared in distilled water and different doses of C. surattensis seed extract $(250 \mathrm{mg} / \mathrm{kg}$ b.w. and $500 \mathrm{mg} / \mathrm{kg}$ b.w.) and silymarin (200 $\mathrm{mg} / \mathrm{kg}$ b.w.) were administered orally according to the body weight of mice [34].

2.5.3. Mice Groupings and Treatments. Fifteen adult male Swiss albino mice were divided into 5 groups and each group consists of 3 mice each (Table 1). The pretreated normal control group received $10 \%$ dimethyl sulfoxide (DMSO) orally. The induced group was pretreated with 10\% DMSO orally and given paracetamol once only (dose $1 \mathrm{~g} / \mathrm{kg}$ b.w.) orally. The treatment Group I received orally both doses of $250 \mathrm{mg} / \mathrm{kg}$ b.w. of C. surattensis seed extract and $1 \mathrm{~g} / \mathrm{kg}$ b.w. paracetamol, while the treatment Group II received orally both doses of $500 \mathrm{mg} / \mathrm{kg}$ bw of C. surattensis seed extract and $1 \mathrm{~g} / \mathrm{kg}$ bw paracetamol, respectively. The positive control group was given silymarin at the dose of $200 \mathrm{mg} / \mathrm{kg}$ b.w. and paracetamol at the dose of $1 \mathrm{~g} / \mathrm{kg}$ b.w. The mice in treatment and positive control groups were pretreated with the respective dose of seed extract/silymarin orally once daily for 7 consecutive days. Paracetamol dose at $1 \mathrm{~g} / \mathrm{kg}$ b.w. was given to mice to induce hepatotoxicity. The oral administration of paracetamol was performed 3 hours after the last seed extract/silymarin administration on the 7 th day 
TABLE 1: Mice groupings and administrated treatments.

\begin{tabular}{|c|c|}
\hline Groups & Treatment \\
\hline Negative control & $10 \%$ DMSO \\
\hline Induced & $\begin{array}{c}1.0 \mathrm{~g} / \mathrm{kg} \text { paracetamol per body } \\
\text { weight }\end{array}$ \\
\hline Treatment Group I & $\begin{array}{c}250 \mathrm{mg} / \mathrm{kg} \text { seed extract per body } \\
\text { weight + paracetamol }\end{array}$ \\
\hline Treatment Group II & $\begin{array}{c}500 \mathrm{mg} / \mathrm{kg} \text { seed extract per body } \\
\text { weigh + paracetamol }\end{array}$ \\
\hline Positive control & $\begin{array}{c}200 \mathrm{mg} / \mathrm{kg} \text { silymarin per body } \\
\text { weight + paracetamol }\end{array}$ \\
\hline
\end{tabular}

except for the normal control group, which received only $10 \%$ DMSO. All mice were euthanized after 48 hours after paracetamol-induced hepatotoxicity [34].

2.5.4. Biochemical Analysis. The mice of each group were anaesthetized with ketamine/xylazine and blood was collected directly from the heart. Then centrifuged at $3000 \mathrm{rpm}$ for 15 minutes to separate the serum and kept at $4^{\circ} \mathrm{C}$ for analysis of various biochemical parameters including ALT, AST, and ALP [35]. All the analyses were performed using Hitachi 902 Automatic Analyzer using the adapted reagents from Roche (Germany) at Gribbles Pathology Laboratory Malaysia (M) Sdn. Bhd., Penang, Malaysia.

2.5.5. Determination Body Weight and Relative Liver Weight. The mice were weighed daily during the study and the body weights of the mice were determined and recorded. After the mice were euthanized, the livers were isolated and washed with saline and weights were determined by using an electronic balance [36]. The liver weight was expressed with respect to relative liver weight. Relative liver weight was calculated using this formula:

$$
\begin{aligned}
& \text { Relative liver weight }(\%) \\
& =\frac{\text { Liver organ weight } \times 100}{\text { Body weight }} .
\end{aligned}
$$

2.5.6. Evaluation of the Antioxidant Status in the Liver Homogenate. Livers were perfused with saline and homogenized in chilled potassium chloride (1.17\%) using a homogenizer to determine the in vivo antioxidant level in the liver tissues.

(1) Glutathione (GSH) Activity Assay. The GSH activity was quantified by using commercially available Glutathione Assay Kit (Sigma-Aldrich, USA). Initially, $10 \mathrm{~mL}$ of liver homogenate was added and mixed properly with $150 \mu \mathrm{L}$ of working solution consisting of $1.5 \mathrm{mg} / \mathrm{mL} \mathrm{DTNB}, 6 \mathrm{U} / \mathrm{mL}$ glutathione reductase, and $1 \mathrm{x}$ assay buffer in a 96 well-plate before being incubated for $5 \mathrm{~min}$. Subsequently, $50 \mathrm{~mL}$ of NADPH solution with a concentration of $0.16 \mathrm{mg} / \mathrm{mL}$ was added to each well in a 96 well-plate. Finally, the absorbance was measured by using an ELISA Plate Reader (Molecular
Devices Inc., USA) at $412 \mathrm{~nm}$ wavelength at $1 \mathrm{~min}$ intervals for $5 \mathrm{~min}$ [37].

(2) The Malonyldialdehyde (MDA) Assay. Each liver homogenate $(200 \mu \mathrm{L})$ was diluted with $800 \mu \mathrm{L}$ of PBS and mixed with $25 \mu \mathrm{L}$ of $8.8 \mathrm{mg} / \mathrm{mL}$ butylhydroxytoluene and $500 \mu \mathrm{L}$ of $50 \%$ trichloroacetic acid. The mixture was vortexed, incubated for $2 \mathrm{~h}$ on ice, and centrifuged at $2000 \times \mathrm{g}$ for $15 \mathrm{~min}$. The supernatant $(1 \mathrm{~mL})$ was transferred into a new tube and mixed with $75 \mu \mathrm{L}$ of $0.1 \mathrm{M}$ EDTA and $250 \mu \mathrm{L}$ of $0.05-\mathrm{M} 2-$ thiobarbituric acid. The mixture was boiled for $15 \mathrm{~min}$ and allowed to cool to room temperature before the absorbance was measured at 532 and $600 \mathrm{~nm}$ in an ELISA Plate Reader (Molecular Devices Inc., USA) [37].

(3) Super Oxide Dismutase (SOD) Assay. Initially, a master mixture comprised $0.1 \mathrm{~mol} / \mathrm{L}$ phosphate buffer, $0.15 \mathrm{mg} / \mathrm{mL}$ sodium cyanide in $0.1 \mathrm{~mol} / \mathrm{L}$ ethylenediaminetetraacetic acid (EDTA), $1.5 \mathrm{mmol} / \mathrm{L}$ nitroblue tetrazolium, and $0.12 \mathrm{mmol} / \mathrm{L}$ riboflavin was prepared. Afterward, $200 \mu \mathrm{L}$ of master mixture was added to $100 \mu \mathrm{L}$ of serially diluted liver homogenates in a 96 well-plate before mixed thoroughly. Lastly, the absorbance was read by using an ELISA Plate Reader (Molecular Devices Inc., USA) at $560 \mathrm{~nm}$ wavelength and the SOD activity in the liver homogenate was expressed as units SOD/mg protein [37].

2.5.7. Histopathological Observations. The liver samples of the mice were fixed in $10 \%$ buffered formalin. After fixation, the livers were dehydrated in a graded series of alcohol, cleared in xylene, and embedded in paraffin wax. Multiple $5 \mu \mathrm{m}$ sections from each block were mounted on slides. After staining with hematoxylin and eosin $(\mathrm{H} \& \mathrm{E})$, slides were examined under a microscope for histopathological changes [34].

2.6. Statistical Analysis. Data are expressed as mean \pm Standard Deviation (SD). Significance was evaluated using $t$-test and one-way ANOVA test (SPSS 13.0, SPSS Inc., Chicago, III) followed by Tukey post hoc multiple comparisons test for unpaired values. Regression analysis was performed to calculate the dose-response relation. Linear regression analysis was performed to find out the correlation coefficient. $p<0.05$ was considered statistically significant.

\section{Results}

3.1. Extract Yield. The extraction was carried out using matured C. surattensis seeds. The weight of powdered seeds was $52.22 \mathrm{~g}$. The weight of the seeds extract in paste form was $14.92 \mathrm{~g}$. The extraction process yielded $28.57 \%$ of $C$. surattensis seeds extract.

3.2. Total Phenolic Content. The total phenolic content of the C. surattensis seed extract was expressed as mg gallic acid equivalent/g dry weight and calculated by using the gallic acid standard curve equation: $y=0.052 x+0.311\left(R^{2}=0.992\right)$. The total phenolic content of $C$. surattenis seed extract was $100.99 \mathrm{mg}$ GAE/g dry weight. 


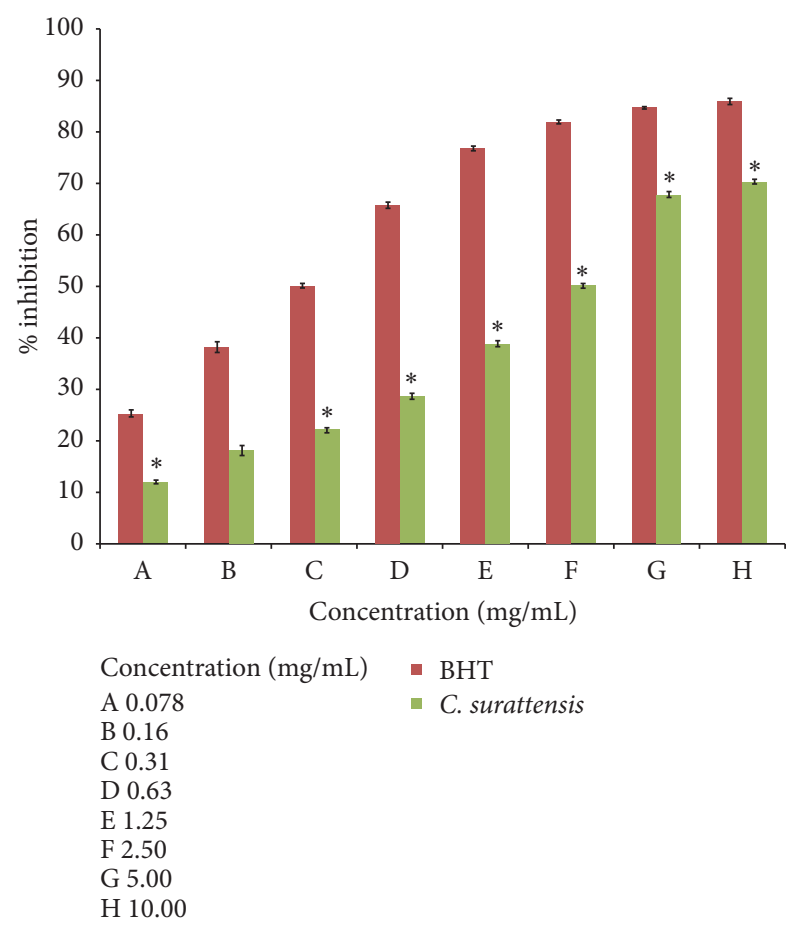

Figure 1: Percentage inhibition of methanolic seed extract of $C$. surattensis on DPPH free radicals compared to butylated hydroxytoluene (BHT). Each value is expressed as mean $\pm \mathrm{SD}(n=3)$, ${ }^{*} p<0.05$ compared with BHT.

\subsection{Radical Scavenging Activity}

3.3.1. 2,2-Diphenyl-1-picrylhydrazyl (DPPH) Radical Scavenging Assay. Figures 1 and 2 show that the dose-response activity of DPPH radical scavenging activity of the methanol extract of the $C$. surattensis seed compared to the standard antioxidant BHT. The methanolic seed extract showed the highest scavenging activity, $70.39 \% \pm 0.50$ at $10 \mathrm{mg} / \mathrm{mL}$, and lowest, $12.18 \% \pm 0.35$ at $0.078 \mathrm{mg} / \mathrm{mL}$. The methanolic seed extract exhibited concentration dependent antioxidant activity by inhibiting DPPH radical with inhibitory concentration $50 \%\left(\mathrm{IC}_{50}\right)$ value of $2.13 \pm 1.01 \mathrm{mg} / \mathrm{mL}$ and $\mathrm{BHT}$ was $0.31 \pm$ $0.17 \mathrm{mg} / \mathrm{mL}$ (Figures 1 and 2).

3.3.2. Nitric Oxide (NO) Radical Scavenging Assay. Dosedependent NO scavenging activity of the methanol extract of the C. surattensis seed is shown in Figures 3 and 4. The methanolic seed extract showed the highest scavenging activity $(67.60 \% \pm 1.07)$ at $1000 \mu \mathrm{g} / \mathrm{mL}$ and lowest $(13.42 \% \pm$ $0.13)$ at $1.95 \mu \mathrm{g} / \mathrm{mL}$. The methanolic seed extract of $C$. surattensis exhibited concentration dependent antioxidant activity by inhibiting nitric oxide radical with IC50 value of $164.06 \pm 1.13 \mu \mathrm{g} / \mathrm{mL}$ and ascorbic acid was $22.39 \pm 0.98 \mu \mathrm{g} / \mathrm{mL}$ (Figure 3). The IC50 values of the ascorbic acid were comparatively lower than seed extract which indicates higher antioxidant activity of ascorbic acid compared to the seed extract (Figure 4). Previously, Parul et al. [38] demonstrated that ascorbic acid has a strong antioxidant activity on the NO radical.

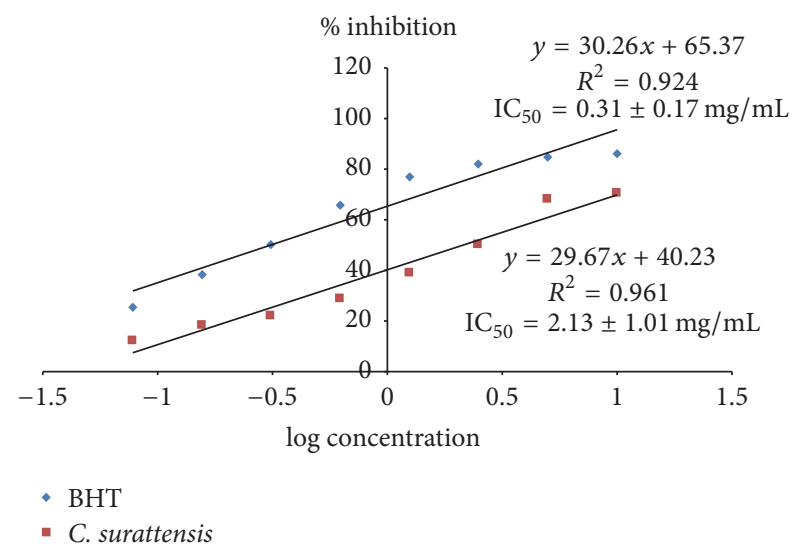

FIGURE 2: Inhibition effect of C. surattensis seed extract on DPPH free radicals compared with butylated hydroxytoluene (BHT).

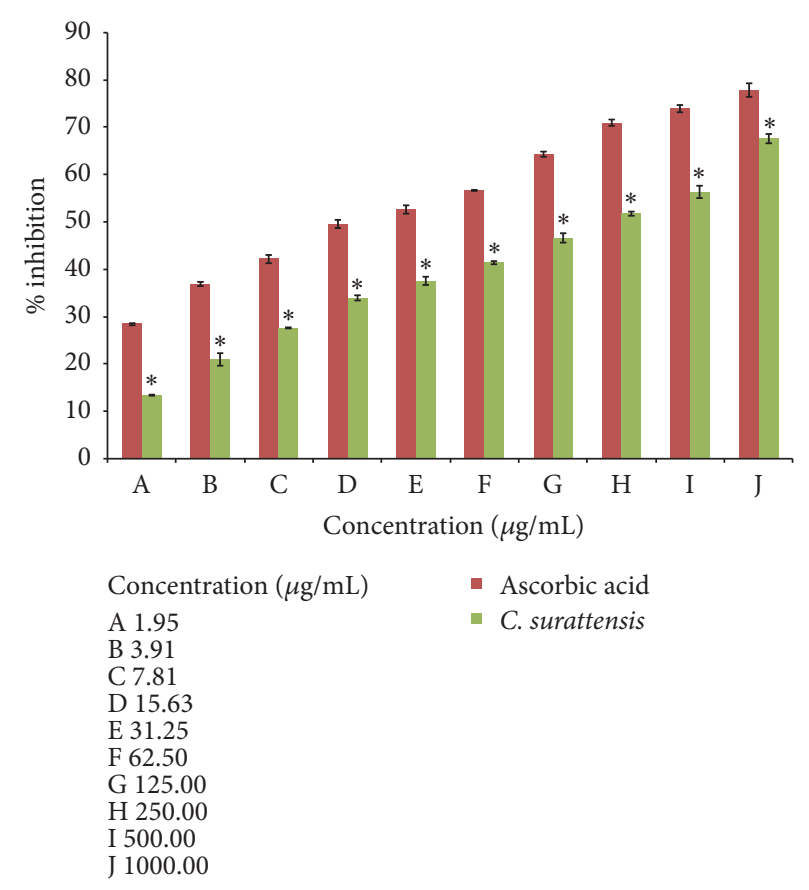

FIgURE 3: Percentage inhibition of methanolic seed extract of $C$. surattensis on nitric oxide radicals compared to ascorbic acid. Each value is expressed as mean $\pm \mathrm{SD}(n=3),{ }^{*} p<0.05$ compared with ascorbic acid.

3.3.3. Reducing Activity. The dose-response action for the reducing activity of methanol extract of $C$. surattensis seed is shown in Figure 5. The seed extract demonstrated reducing power activity in all the concentration tested, in a concentration-dependent manner. The seed extract reduced ferricyanide complex $(\mathrm{Fe} 3+)$ to the ferrous form $(\mathrm{Fe} 2+)$ and this showed that the seed extract has antioxidant properties. The methanolic seed extract showed the highest absorbance, $1.366 \pm 0.0036$ at $10.00 \mathrm{mg} / \mathrm{mL}$, and lowest, $0.235 \pm 0.0021$ at $0.02 \mathrm{mg} / \mathrm{mL}$. The higher absorbance of the reaction solution indicates the greater reducing power and greater antioxidant activity [39]. Ascorbic acid showed greater reducing power than that of the $C$. surattensis seed extract. 


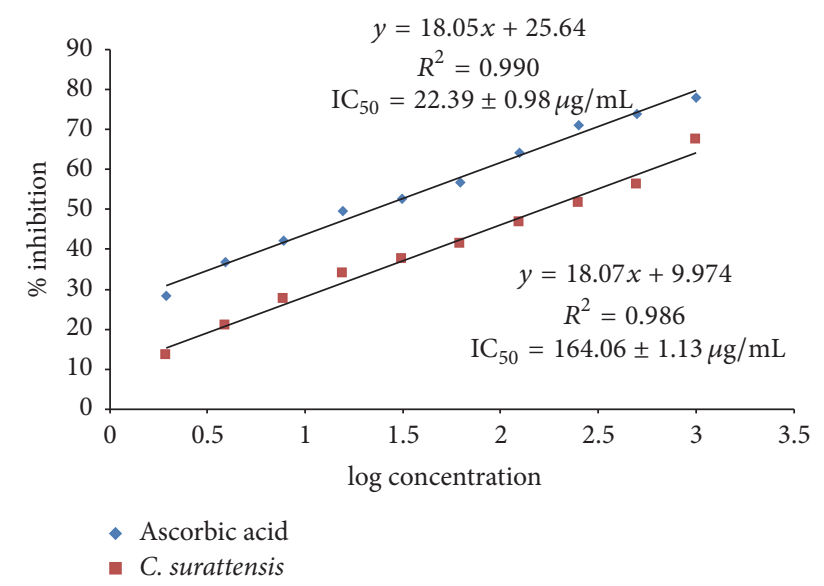

FIgURE 4: Inhibition effect of C. surattensis seed extract on nitric oxide radicals compared with ascorbic acid.

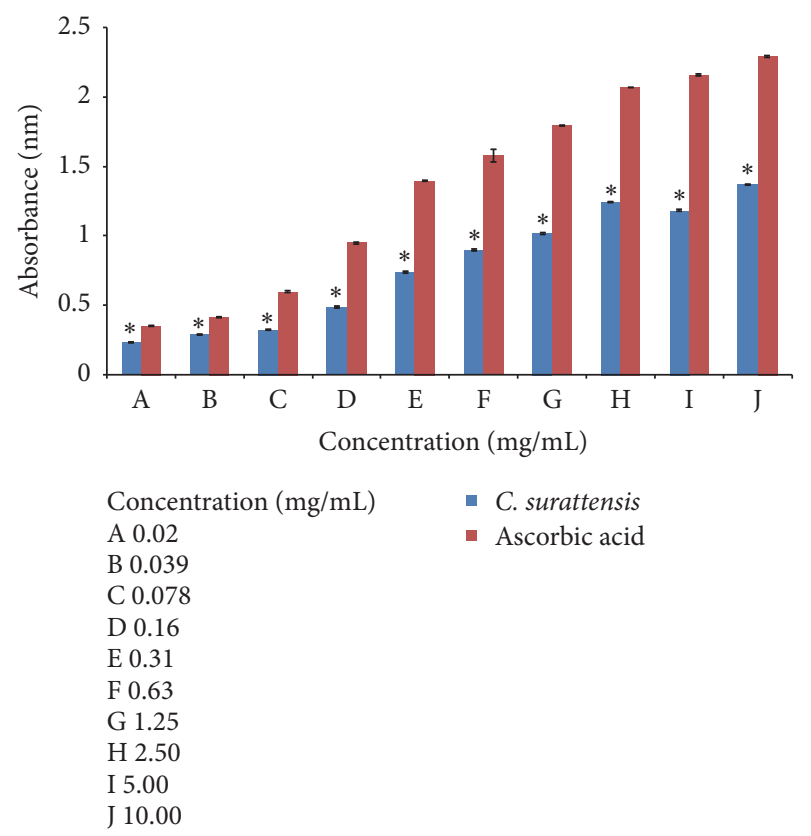

FIGURE 5: Reducing power of methanolic seed extract of C. surattensis compared to ascorbic acid. Each value is expressed as mean \pm SD $(n=3),{ }^{*} p<0.05$ compared with ascorbic acid.

\subsection{In Vivo Antihepatotoxic Activities}

3.4.1. Determination of Body Weight and Relative Liver Weight. Table 2 shows that the average body weights of the experimental animals were not affected by paracetamol, silymarin, and C. surattensis seed extract. The paracetamol administration caused a significant increase in the average liver weight of the paracetamol-induced group compared to the negative control group. The pretreatment with $C$. surattensis seed extract, at doses of 250 and $500 \mathrm{mg} / \mathrm{kg}$ b.w., and silymarin at a dose of $200 \mathrm{mg} / \mathrm{kg}$ bw significantly reduced the increased liver weight in paracetamol-induced group. A significant elevation of relative liver weight was seen in paracetamolinduced group, $8.15 \pm 0.35 \%$, when compared to the negative control group, $5.82 \pm 0.31 \%$, indicating the paracetamolinduced hypertrophy of these tissues. By contrast, C. surattensis seed extract, at dose of $250 \mathrm{mg} / \mathrm{kg}$ bw and $500 \mathrm{mg} / \mathrm{kg}$ bw, and silymarin at a dose of $200 \mathrm{mg} / \mathrm{kg}$ bw in combination with paracetamol significantly $(p<0.05)$ reduced the value of the relative liver weights to $5.99 \pm 0.18 \%, 6.03 \pm 0.47 \%$, and $6.12 \pm 0.41 \%$, respectively, suggesting the possibility of $C$. surattensis seed extract to give protection against liver injury upon paracetamol administration.

3.4.2. Biochemical Analysis. The effect of C. surattensis seed extract on liver marker enzymes (ALT, AST, and ALP) is displayed in Table 3. The data exhibited that the negative control group demonstrated a normal range of ALT, AST, and ALP levels. However, paracetamol administration caused a significant elevation in the ALT, AST, and ALP levels to $1689 \pm 102.14 \mathrm{U} / \mathrm{L}, 2998 \pm 189.22 \mathrm{U} / \mathrm{L}$, and $341.51 \pm 38.11 \mathrm{U} / \mathrm{L}$, respectively, compared to the negative control group with pretreated 10\% DMSO. A single oral dose of paracetamol at $1 \mathrm{~g} / \mathrm{kg}$ bw caused a drastic increase in the serum liver marker enzyme activities of ALT, AST, and ALP [40], indicating an acute hepatotoxicity induced by administration of paracetamol. According to the Table 3 data, the biochemical parameters of the C. surattensis seed extract pretreated group were greater than those of the negative control group $(p<$ 0.05), but it showed much lower levels of ALT, AST, and ALP than the paracetamol-induced group; that is, the extract treatment significantly reduced the previously elevated levels of ALT, AST, and ALP in liver tissue of hepatotoxic mice.

3.4.3. The Antioxidant Status in the Liver Tissues. The in vivo antioxidant level in the liver tissues of paracetamolintoxicated mice pretreated with C. surattensis seed extract was evaluated by various antioxidant assays, namely, GSH assay, SOD assay, and MDA assay (Table 4). The data exhibited that the negative control group revealed a normal range of GSH, SOD, and MDA levels, while the paracetamol-treated group displayed elevated levels of MDA and with decreased level of GSH and SOD, approving that paracetamol triggered liver injury at higher doses. However, the C. surattensis seed extract or silymarin pretreatment significantly elevated the previously dropped levels of GSH and SOD which led to depletion of the MDA levels in liver tissue. These findings clearly demonstrating the in vivo antioxidant activity C. surattensis seed extract at the dose of $250 \mathrm{mg} / \mathrm{kg}$ and $500 \mathrm{mg} / \mathrm{kg}$ by significantly reversing $(p<0.05)$ the effect produced by the paracetamol triggered liver injury.

3.4.4. Histopathological Observation. To further explore the biochemical analysis findings, histopathological observation was conducted on liver tissue. Liver sections taken from paracetamol-induced mice (Figure 6) had severe necrosis, vacuolar degeneration, loss of cellular boundaries, and obstruction of sinusoids, and hepatocytes were disrupted and showed hypertrophy compared to the healthy negative control group. The accumulation of neutrophils was also seen in the central vein. The neutrophils act as an indicator of the occurrence of cell damage as they are absent in 
TABLE 2: Effect of C. surattensis seed extract on the body and liver weight of mice in paracetamol induced hepatotoxicity.

\begin{tabular}{lcccc}
\hline Groups & Dose $(\mathrm{mg} / \mathrm{kg})$ & $\begin{array}{c}\text { Body weight, } \\
\text { BW (g) }\end{array}$ & $\begin{array}{c}\text { Liver weight, } \\
\text { LW (g) }\end{array}$ & $\begin{array}{c}\text { Relative liver } \\
\text { weight }(\%) \\
(\mathrm{LW} / \mathrm{BW})\end{array}$ \\
\hline $\begin{array}{l}\text { 10\% DMSO pretreated negative } \\
\text { control }\end{array}$ & - & $39.88 \pm 3.15$ & $2.32 \pm 3.01$ & $5.82 \pm 0.31$ \\
Paracetamol-induced & - & $38.99 \pm 5.12^{* *}$ & $3.18 \pm 5.01^{* *}$ & $8.15 \pm 0.35^{* *}$ \\
Silymarin + paracetamol & 200.00 & $41.51 \pm 3.12^{*}$ & $2.54 \pm 2.82^{*}$ & $6.12 \pm 0.41^{*}$ \\
Seed extract + paracetamol & 250.00 & $39.85 \pm 3.12^{*}$ & $2.39 \pm 3.08^{*}$ & $5.99 \pm 0.18^{*}$ \\
Seed extract + paracetamol & 500.00 & $40.08 \pm 3.48^{*}$ & $2.42 \pm 3.40^{*}$ & $6.03 \pm 0.47^{*}$ \\
\hline
\end{tabular}

Results are expressed in means $\pm \mathrm{SD}(n=3)$.

${ }^{*} p<0.05$ compared with paracetamol-induced group.

*** $p<0.05$ compared with $10 \%$ DMSO pretreated negative control group.

TABLE 3: Effect of C. surattensis seed extract on ALT, AST, and ALP (U/L) levels of mice in paracetamol-induced hepatotoxicity.

\begin{tabular}{lcccc}
\hline Groups & Dose $(\mathrm{mg} / \mathrm{kg})$ & ALT $(\mathrm{U} / \mathrm{L})$ & AST $(\mathrm{U} / \mathrm{L})$ & ALP $(\mathrm{U} / \mathrm{L})$ \\
\hline 10\% DMSO pretreated negative control & - & $16.72 \pm 2.31$ & $89.89 \pm 4.12$ & $114.3 \pm 4.22$ \\
Paracetamol-induced group & - & $1689 \pm 102.14^{\mathrm{a}}$ & $2998 \pm 189.22^{\mathrm{a}}$ & $341.51 \pm 38.11^{\mathrm{a}}$ \\
Silymarin + paracetamol & 200.00 & $601.1 \pm 184.47^{\mathrm{ab}}$ & $921.3 \pm 298.21^{\mathrm{ab}}$ & $185.47 \pm 12.21^{\mathrm{ab}}$ \\
Seed extract + paracetamol & 250.00 & $1105 \pm 204.28^{\mathrm{ab}}$ & $2031 \pm 388.12^{\mathrm{ab}}$ & $271.55 \pm 27.32^{\mathrm{ab}}$ \\
Seed extract + paracetamol & 500.00 & $801.43 \pm 99.21^{\mathrm{ab}}$ & $1389 \pm 212.33^{\mathrm{ab}}$ & $231.12 \pm 11.17^{\mathrm{ab}}$ \\
\hline
\end{tabular}

Results are expressed in means $\pm \mathrm{SD}(n=3)$.

${ }^{a} p<0.05$ compared with $10 \%$ DMSO pretreated negative control group.

${ }^{\mathrm{ab}} p<0.05$ compared with paracetamol-induced group.

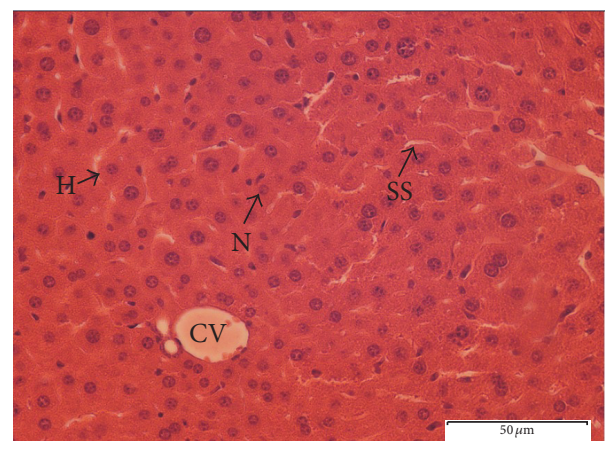

FIGURE 6: Light microphotograph of negative control liver. (H: hepatocytes; N: nucleus; SS: sinusoid; CV: central vein). Magnification: 40x.

normal healthy cells (Figure 7). Histopathological analysis showed that silymarin as well as the seed extract at a dose of $500 \mathrm{mg} / \mathrm{kg}$ b.w. significantly improved the degree of hepatocytes degeneration and necrosis in paracetamolinduced mice.

The hepatocyte nucleases are at a recovery stage and there are very minimal numbers of neutrophils surrounding the central vein.

The pretreated group with seed extract at a dose of $500 \mathrm{mg} / \mathrm{kg}$ b.w. (Figure 9) and silymarin at a dose of $200 \mathrm{mg} /$ $\mathrm{kg}$ b.w. (Figure 10) was very close to the negative control group which showed intact liver cells. Histopathological liver sections of control group showed normal cellular structure and clear central vein, and hepatic cells were distinct and

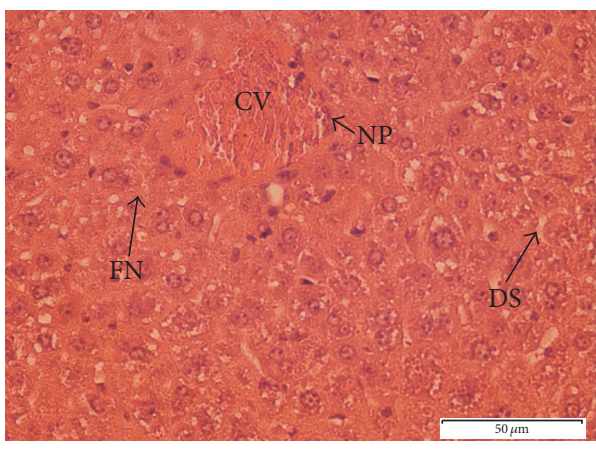

FIGURE 7: Light microphotograph of paracetamol-induced liver. (NP: neutrophil; DS: dilated sinusoid; FN: focal necrosis; CV: central vein). Magnification: 40x.

separated by sinusoidal spaces. The seed extract at a dose of $250 \mathrm{mg} / \mathrm{kg}$ b.w. did not show significant improvement over the effect of paracetamol on the liver (Figure 8). Though the extent of hepatocytes degeneration was a little lower than in the paracetamol-induced group, liver architecture (necrosis) was slightly improved.

\section{Discussion}

4.1. Total Phenolic Content. This study showed that C. surattensis seed extract contained favourable amount of phenolic compounds. A few studies have reported that C. surattensis plant parts possess a significant total phenolic content. For 
TABLE 4: Effect of C. surattensis seed extract on oxidative status in paracetamol-induced hepatotoxicity mice liver tissue.

\begin{tabular}{|c|c|c|c|c|}
\hline Groups & Dose $(\mathrm{mg} / \mathrm{kg})$ & $\begin{array}{c}\mathrm{GSH}(\mathrm{mg} / \mathrm{mg} \\
\text { protein) }\end{array}$ & $\begin{array}{c}\text { SOD (U/mg } \\
\text { protein) }\end{array}$ & $\begin{array}{l}\text { MDA (nmol/mg } \\
\text { protein) }\end{array}$ \\
\hline $10 \%$ DMSO pretreated negative control & - & $4.13 \pm 0.12$ & $120.82 \pm 1.53$ & $1.45 \pm 0.11$ \\
\hline Paracetamol-induced & - & $2.35 \pm 0.05$ & $50.07 \pm 1.22^{* *}$ & $5.04 \pm 0.08^{* *}$ \\
\hline Silymarin + paracetamol & 200.00 & $4.40 \pm 0.04$ & $136.69 \pm 1.31^{*}$ & $1.64 \pm 0.01^{*}$ \\
\hline Seed extract + paracetamol & 250.00 & $3.80 \pm 0.01$ & $108.56 \pm 3.51^{*}$ & $1.87 \pm 0.08^{*}$ \\
\hline Seed extract + paracetamol & 500.00 & $4.21 \pm 0.09$ & $130.34 \pm 1.00^{*}$ & $1.68 \pm 0.05^{*}$ \\
\hline
\end{tabular}

Results are expressed in means $\pm \operatorname{SD}(n=3)$.

${ }^{*} p<0.05$ compared with paracetamol-induced group.

** $p<0.05$ compared with $10 \%$ DMSO pretreated negative control group.

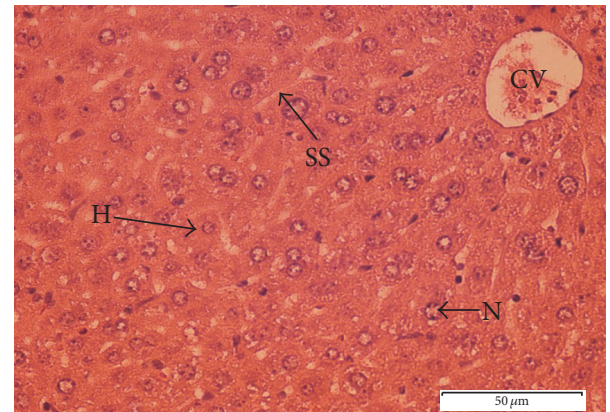

FIGURE 8: Light microphotograph of liver cells of mice treated with C. surattensis (250 mg/kg) (H: hepatocytes; N: nucleus; SS: sinusoid; $\mathrm{CV}$ : central vein). Magnification: 40x.

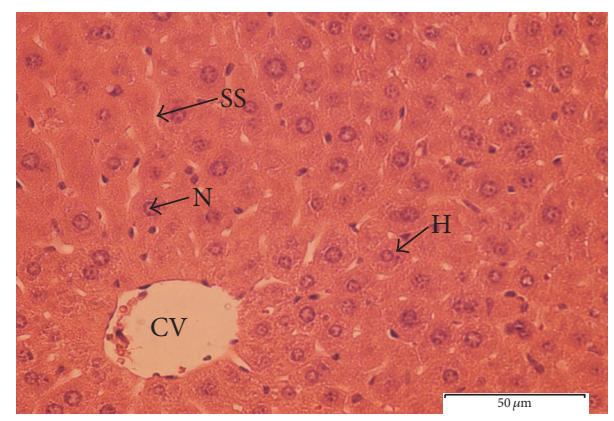

FIGURE 9: Light microphotograph of liver cells of mice treated with C. surattensis (500 mg/kg) (H: hepatocytes; N: nucleus; SS: sinusoid; CV: central vein). Magnification: 40x.

example, Sangetha et al. [24] reported that phenolic compounds were found in flower, stem, leaves, and pod of $C$. surattensis extracts and among the plant parts, only the flower, stem, and leaves of C. surattensis extracts showed a significant high content of total phenolics. Chew et al. [41] have reported that the flowers of C. surattensis extract contain total phenolic content of $3330 \pm 309 \mathrm{mg} \mathrm{GAE} / 100 \mathrm{~g}$.

The result of the present study clearly indicated that the methanol extract of C. surattensis seed exhibited the presence of phenolic compounds and there was a strong positive correlation with the DPPH radical scavenging activity $(r=$ $0.968)$ and NO radical scavenging activity $(r=0.979)$. The same relationship was also observed between phenolics

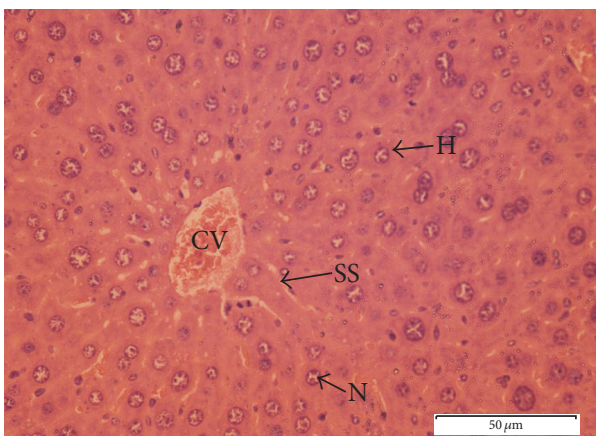

FIGURE 10: Light microphotograph of liver cells of mice treated with silymarin (H: hepatocytes; N: nucleus; SS: sinusoid; CV: central vein). Magnification: 40x.

and antioxidant activity in Sea Buckthorn extracts [42]. Kaneria et al. [43] reported that there are high correlation between phenolic contents and antioxidant activities of some medicinal plant extracts such as Azadirachta indica, Hemidesmus indicus, Manilkara zapota, Psoralea corylifolia, Rubia cordifolia, and Tinospora cordifolia. These show that the presence of a significant amount of total phenolic content in the seed extract might effectively inhibit radicals and contribute directly to the effective antioxidant activities. The phenolic compound in plant donates their hydrogen atoms from their hydroxyl groups to radicals and form a stable phenoxyl radical and this reaction contributes to their antioxidant activity [44].

\subsection{Radical Scavenging Activity}

4.2.1. 2,2-Diphenyl-1-picrylhydrazyl (DPPH) Radical Scavenging Assay. The DPPH radical is regularly used as a substrate to evaluate the antioxidant activity of medicinal plant; it is a stable free radical that can receive an electron to become a stable molecule. The C. surattensis seed extract with higher concentration showed higher bleaching ability of the $\mathrm{DPPH}^{\circ}$ solution with greater hydrogen atom donating activity and higher antioxidant activity. The antioxidant activity of the extract might be attributed to the hydrogen donating ability of the phenolic hydroxyl groups $[45,46]$. The DPPH scavenging activities of C. surattensis seed extracted with acetone have been reported in previous study by Deepak et al. [27]. 
According to the study, acetone extract showed maximum antioxidant activity, $76.11 \%$ than other extracts (methanol, chloroform) in comparison to standard drug, ascorbic acid.

4.2.2. Nitric Oxide (NO) Radical Scavenging Assay. Nitric oxide (NO) is a key chemical facilitator involved in the regulation of various physiological processes. Higher concentration of $\mathrm{NO}$ is related with numerous diseases. Oxygen molecules react with the excess amount of NO to generate nitrite and peroxynitrite anions, which eventually act as free radicals [47]. The results of this study indicate that all the concentrations of $C$. surattensis seed extract and ascorbic acid tested have noticeable inhibition effect on nitric oxide radicals. The seed extract exhibited antioxidant activity through competing with oxygen to scavenge for the nitrite radical that was generated from sodium nitroprusside (SNP) at physiological $\mathrm{pH}$ in an aqueous environment. The C. surattensis seed extract acts as a potent antioxidant and donate protons to the nitrite radical. This decreased the absorbance and increased the percentage of inhibition. The decrease in absorbance and increase in percentage of inhibition were used to measure the extent of nitrite radical scavenging and antioxidant activity [48]. The NO scavenging activity of phenolic compounds is known [49-51], and this suggests that these compounds in the seed extract might contribute to the NO scavenging activity observed in this study.

4.2.3. Reducing Activity. Reducing power assay is commonly used to assess the capability of a natural antioxidant to donate an electron [52]. This finding of this study affirms the reducing power of $C$. surattensis seed extract. It was hypothesized that the reducing power of C. surattensis seed extract might be due to their electron-donating ability and higher amount of reductants contains. Electrons or hydrogen atoms might react with free radicals to stabilize or transform the free radicals into more stable and nonreactive products subsequently blocking the free radical chain reactions [53, 54]. Therefore, C. surattensis seed extract could act as electron donors to free radicals and then dismiss the free radical chain reactions.

\subsection{In Vivo Antihepatotoxic Activities}

4.3.1. Determination of Body Weight and Relative Liver Weight. The body weight of the mice in this study was not affected by the treatment of paracetamol, silymarin, and C. surattensis seed extract. This finding was parallel with the findings by Saad et al. [55] on the failure of thioacetamide to cause changes in body weight of rats in acute liver injury study. The increase in the liver weight and relative liver weight of paracetamol-induced liver hepatotoxicity group compared to negative control, silymarin and $C$. surattensis seed extract (doses of $250 \mathrm{mg} / \mathrm{kg}$ b.w. and $500 \mathrm{mg} / \mathrm{kg}$ b.w.), pretreated groups might be associated with the blocking of hepatic triglyceride secretion into plasma or might be due to the very large increase in liver hemoglobin [56]. On the other hand, the pretreatment with silymarin and seed extract prevented the increase in liver weight and relative liver weight when compared to paracetamol-induced group, which proved the significant hepatoprotective effect.

4.3.2. Biochemical Analysis. Paracetamol induced mice liver damage in this study because of the formation of toxic metabolite, NAPQI, which is initially detoxified by conjugation with glutathione to form mercapturic acid [57]. The overdose of paracetamol used in this study caused the glutathione content of hepatocytes exhausted and the hepatocytes become vulnerable to the noxious effects of NAPQI resulting in liver cell necrosis or liver failure that eventually increased the ALT and AST levels $[58,59]$ which may explain the findings of this study. It was concluded that a single dose of paracetamol had caused damage to the parenchymal cell in the liver that leads to the leakage of the aminotransferases (ALT and AST) into the blood serum, resulting in increased of its concentrations. The aminotransferases that are released into the blood circulation when there is hepatic necrosis making the enzymes measurable in serum [60-62].

However, pretreatment of high dose of C. surattensis seed extract at $500 \mathrm{mg} / \mathrm{kg}$ b.w. and silymarin at $200 \mathrm{mg} / \mathrm{kg}$ b.w. exhibited an ability to counteract the toxic effect of paracetamol by decreasing the level of these enzymes. The pretreatment of C. surattensis seed extract at a dose of $250 \mathrm{mg} / \mathrm{kg}$ b.w. caused a slight decrease in the elevated serum liver enzymes. The results of this study supported the generally accepted view that serum levels of aminotransferases return to normal levels with the healing of hepatic parenchyma and regeneration of hepatocytes $[63,64]$. The decrease in AST and ALT levels by the seed extract was also an indication of stabilization of plasma membrane as well as repair of hepatic tissue damage caused by paracetamol.

The pretreatment with the $250 \mathrm{mg} / \mathrm{kg}$ b.w. dose of seed extract slightly reduced the elevated serum liver enzyme levels but not as effective as the treatment with $500 \mathrm{mg} / \mathrm{kg}$ b.w. dose of the seed extract. This proved that C. surattensis seed extract at higher dose, $500 \mathrm{mg} / \mathrm{kg}$ b.w., showed a better hepatoprotective effect compared to the dose at $250 \mathrm{mg} / \mathrm{kg}$ b.w. This might be because the amount of antioxidant polyphenol compound(s) in the extract which render the free radical scavenging activity present at higher dose in $500 \mathrm{mg} / \mathrm{kg}$ b.w. compared with $250 \mathrm{mg} / \mathrm{kg}$ b.w. dose of $C$. surattensis seed extract. Interestingly, the in vitro antioxidant activity study showed that the C. surattensis seed extract exhibited a concentration dependent activity which supports this explanation.

This study also showed that in mice group with paracetamol-induced liver hepatotoxicity, the ALT and AST levels were elevated more compared to the lesser increase in the ALP level. This finding indicated that paracetamol caused cell necrosis at a single dose of $1 \mathrm{~g} / \mathrm{kg}$ b.w. as cell necrosis involves the initial increase of ALT and AST and modest increase in ALP. The ratio of ALT/AST: ALP plays an important role in the determination of the types of liver damage by hepatotoxins. The ratio is greater than or equal to five for cell necrosis injury compared to if the ratio is less than or equal to two for cholestasis injury. 
4.3.3. The Antioxidant Status in the Liver Tissues. The ROS induced oxidative stress inside the cells triggered damage to hepatic parenchymal cells leading to hepatic injury [65]. The raise of ROS levels related with hepatic injury is due to high generation of ROS and reduced scavenging potential of the cells intrinsic antioxidants such as GSH and SOD [65]. Moreover, ROS may cause membrane damage by lipid peroxidation, and MDA is one of the final products of polyunsaturated fatty acids peroxidation in the cells [66]. In this study, paracetamol-induced liver hepatotoxicity significantly reduced the levels of SOD and GSH and elevated the level of MDA, which is a marker of lipid peroxidation, compared to negative control. The overproduction of NAPQI by overdose of paracetamol caused the glutathione content of hepatocytes exhausted and resulting in the reduction of GSH levels in liver tissue $[58,59]$. The C. surattensis seed extract pretreatment was found increased in the level of intrinsic antioxidants such as GSH and SOD, with reduction in the elevated level of MDA, caused by the paracetamol-induced liver hepatotoxicity. Silymarin also caused significant favourable effects on the levels of GSH, SOD, and MDA relative to the paracetamol-induced group. These results propose that C. surattensis seed extract caused hepatoprotective activity linked with the improvement of in vivo antioxidant activity.

4.3.4. Histopathological Observation. The methanolic extract of C. surattensis seeds showed significant hepatoprotective activity on paracetamol-induced liver toxicity when administered at a high dose of $500 \mathrm{mg} / \mathrm{kg}$ orally. The histopathological liver sections of $C$. surattensis seed extract (dose $500 \mathrm{mg} / \mathrm{kg}$ b.w.) pretreated group showed a comparable results to the silymarin pretreated group (dose $200 \mathrm{mg} / \mathrm{kg}$ b.w.) in recovering the paracetamol-induced histopathological lesions. These findings suggest the protection ability of $500 \mathrm{mg} / \mathrm{kg} \mathrm{b.w.} \mathrm{dose}$ of $C$. surattensis seed extract on membrane fragility and thus decreased the leakage of the serum liver enzymes into the blood circulation as observed in this study.

The seed extract which exhibited a concentration dependent activity was not effective in recovering histopathological lesions at a dose of $250 \mathrm{mg} / \mathrm{kg}$ b.w. as C. surattensis seed extract is more effective at higher concentration. The liver histopathological analysis was positively concomitant with the biochemical analysis of this study. The macroscopic appearance of the paracetamol-induced liver showed broad areas of necrosis that helps the leakage of the serum liver enzymes into the blood stream, and this explains the rise in AST, ALT, and ALP in the blood. The hepatotoxic effect of paracetamol is mainly due to generation of free radicals following the depletion of endogenous antioxidants such as glutathione [67]. Therefore, the herbal green C. surattensis seed antioxidant activity is effective in treating paracetamolinduced liver hepatotoxicity by scavenging the free radicals generated by the reaction of paracetamol.

In the present study, the C. surattensis seed extract was administrated at $250 \mathrm{mg} / \mathrm{kg}$ b.w. (low dose) and $500 \mathrm{mg} / \mathrm{kg}$ b.w. (high dose) based on the finding on acute oral toxicity of C. surattensis flower methanolic extract on Swiss albino mice. No sign of toxicity in mice was reported in the study conducted by Sumathy et al. [68]. According to the OECD guidelines for testing of chemicals 420 for testing of chemicals [69], animals should only be administrated a single dose of $5000 \mathrm{mg} / \mathrm{kg}$. Hence in this study, the high dose of $500 \mathrm{mg} / \mathrm{kg}$ bw was selected as $1 / 10$ of the dose that was used in the acute oral toxicity study $(5000 \mathrm{mg} / \mathrm{kg})$ and the low dose of $250 \mathrm{mg} / \mathrm{kg}$ b.w. was 2 times reduction of the high dose. Moreover, there were several studies that used doses of $250 \mathrm{mg} / \mathrm{kg}$ b.w. and $500 \mathrm{mg} / \mathrm{kg}$ b.w. to evaluate the hepatoprotective activity of plants $[34,70]$.

The methanolic extract of C. surattensis seeds in this study showed a good scavenging activity of DPPH and nitric oxide radicals. Hence, the in vitro findings further explained the potential of $C$. surattensis seed hepatoprotective activity in paracetamol-induced liver toxicity in mice and proved that the hepatoprotective activity may be due to the observed redox control of antioxidant activity of C. surattensis seeds. Similar hepatoprotective activity of C. surattensis leaf extract was also determined in the previous study designed to investigate the effect of ethanolic extract of $C$. surattensis leaf on $\mathrm{CCl}_{4}$-induced liver toxicity in rat. The results of the previous study suggested that $C$. surattensis leaf extract significantly reduced the elevated levels of AST, ALT, and ALP in serum which indicates the efficacy of the leaf extract as a redox control hepatoprotective agent [28]. These current histopathological findings further verified the redox control antihepatotoxic activities of C. surattensis seed extract in paracetamol-induced liver toxicity in mice model.

\section{Conclusions}

In conclusion, the results of the present study strongly suggested that $C$. surattensis seed has redox control of antioxidant and antihepatotoxic activities at lower dose by enhancing antioxidant activity and protecting the liver from the toxic effect of the hepatotoxic agents.

\section{Competing Interests}

The authors have no conflict of interests to declare concerning this article.

\section{References}

[1] A. M. Mileo and S. Miccadei, "Polyphenols as modulator of oxidative stress in cancer disease: new therapeutic strategies," Oxidative Medicine and Cellular Longevity, vol. 2016, Article ID 6475624, 17 pages, 2016.

[2] S. Russmann, G. A. Kullak-Ublick, and I. Grattagliano, "Current concepts of mechanisms in drug-induced hepatotoxicity," Current Medicinal Chemistry, vol. 16, no. 23, pp. 3041-3053, 2009.

[3] McNally and F. Peter, GI/Liver Secrets: With STUDENT CONSULT Access, Mosby, St. Louis, Mo, USA, 2006.

[4] Y. Masubuchi, C. Suda, and T. Horie, "Involvement of mitochondrial permeability transition in acetaminophen-induced liver injury in mice," Journal of Hepatology, vol. 42, no. 1, pp. 110-116, 2005.

[5] J. R. Mitchell, D. J. Jollow, W. Z. Potter, J. R. Gillette, and B. B. Brodie, "Acetaminophen induced hepatic necrosis. IV. 
Protective role of glutathione," Journal of Pharmacology and Experimental Therapeutics, vol. 187, no. 1, pp. 211-217, 1973.

[6] B. K. Saroj, D. Mani, and S. K. Mishra, "Scientific validation of polyherbal hepatoprotective formulation against paracetamol induced toxicity," Asian Pacific Journal of Tropical Biomedicine, vol. 2, no. 3, pp. S1742-S1746, 2012.

[7] M. Subramanian, S. Balakrishnan, S. K. Chinnaiyan, V. K. Sekar, and A. N. Chandu, "Hepatoprotective effect of leaves of Morinda tinctoria Roxb. against paracetamol induced liver damage in rats," Drug Invention Today, vol. 5, no. 3, pp. 223-228, 2013.

[8] R. Bhattacharjee and P. C. Sil, "The protein fraction of Phyllanthus niruri plays a protective role against acetaminophen induced hepatic disorder via its antioxidant properties," Phytotherapy Research, vol. 20, no. 7, pp. 595-601, 2006.

[9] Y.-H. Chen, F.-Y. Lin, P.-L. Liu et al., "Antioxidative and hepatoprotective effects of magnolol on acetaminophen-induced liver damage in rats," Archives of Pharmacal Research, vol. 32, no. 2, pp. 221-228, 2009.

[10] A. D. Grypioti, "Liver oxidant stress induced by paracetamol overdose," Internet Journal of Pharmacology, vol. 4, no. 2, p. 7, 2006.

[11] H. Jaeschke, "Reactive oxygen and mechanisms of inflammatory liver injury: present concepts," Journal of Gastroenterology and Hepatology, vol. 26, no. 1, pp. 173-179, 2011.

[12] H. Jaeschke, G. J. Gores, A. I. Cederbaum, J. A. Hinson, D. Pessayre, and J. J. Lemasters, "Mechanisms of hepatotoxicity," Toxicological Sciences, vol. 65, no. 2, pp. 166-176, 2002.

[13] B. Alberts, J. Alexander, L. Julian, R. Martin, R. Keith, and W. Peter, Molecular Biology of the Cell, Garland Publishing, New York, NY, USA, 1994.

[14] C. Richter, J.-W. Park, and B. N. Ames, "Normal oxidative damage to mitochondrial and nuclear DNA is extensive," Proceedings of the National Academy of Sciences of the United States of America, vol. 85, no. 17, pp. 6465-6467, 1988.

[15] V. Latha, M. G. Rajesh, and M. S. Latha, "Hepatoprotective activity of an ayurcedic medicine," Indian Drug, vol. 36, article 47, 1999.

[16] A. G. Agbor and Y. J. Ngogang, "Toxicity of herbal preparations," Cameroon Journal of Ethnobotany, vol. 1, pp. 23-28, 2005.

[17] C. G. Lee, J. H. Koo, and S. G. Kim, "Phytochemical regulation of Fyn and AMPK signaling circuitry," Archives of Pharmacal Research, vol. 38, no. 12, pp. 2093-2105, 2015.

[18] J. K. Kwee, "Yin and Yang of polyphenols in cancer prevention: a short review," Anti-Cancer Agents in Medicinal Chemistry, vol. 16, no. 7, pp. 832-840, 2016.

[19] C. Viegas Jr., V. S. Bolzani, M. Furlan et al., "Further bioactive piperidine alkaloids from the flowers and green fruits of Cassia spectabilis," Journal of Natural Products, vol. 67, no. 5, pp. 908910, 2004.

[20] R. G. Ayo, J. O. Amupitan, and Y. Zhao, "Cytotoxicity and antimicrobial studies of 1,6,8-trihydroxy-3-methylanthraquinone (emodin) isolated from the leaves of Cassia nigricans Vahl," African Journal of Biotechnology, vol. 6, no. 11, pp. 1276-1279, 2007.

[21] R. N. Chopra, S. L. Nayer, and I. C. Chopra, Glossary of Indian Medicinal Plants, Council of Scientific and Industrial Research, New Delhi, India, 1956.

[22] L. M. Perry, Medicinal Plants of East and Southeast Asia, MIT Press, Cambridge, Mass, USA, 1980.
[23] I. H. Burkill, "A dictionary of the economic products of the malay peninsula," in Government of Malaysia and Singapore, Ministry of Agriculture and Cooperatives, Government of Malaysia and Singapore, Ministry of Agriculture and Cooperatives, Kuala Lumpur, Malaysia, 1935.

[24] S. Sangetha, S. Sasidharan, Z. Zuraini, and S. Suryani, "Antioxidant activity of methanolic extracts of Cassia surattensis," Pharmacologyonline, vol. 2, pp. 829-838, 2008.

[25] V. Sumathy, Z. Zakaria, Y. Chen et al., "Evaluation of the effect of Cassia surattensis Burm. f., flower methanolic extract on the growth and morphology of Aspergillus niger," European Review for Medical and Pharmacological Sciences, vol. 17, no. 12, pp. 1648-1654, 2013.

[26] R. Ramesh Petchi, C. Vijaya, and G. S. Devika, "Evaluation of anti-diabetic activity of Cassia surattensis Burm. flower in streptozotocin induced diabetic rats," International Journal of Research in Pharmaceutical Sciences, vol. 2, no. 2, pp. 200-205, 2012.

[27] K. Deepak, A. Shefali, and V. Ankit, "Fatty acid composition and antimicrobial and antioxidant activity of Cassia glauca seed extracts," International Journal of Phytopharmacology, vol. 4, no. 2, pp. 113-118, 2013.

[28] S. A. El-Sawi and A. A. Sleem, "Flavonoids and hepatoprotective activity of leaves of Senna Surattensis (Burm.f.) in $\mathrm{CCl}_{4}$ induced hepatotoxicity in rats," Australian Journal of Basic and Applied Sciences, vol. 4, no. 6, pp. 1326-1334, 2010.

[29] S. L. Jothy, Z. Zuraini, and S. Sasidharan, "Phytochemicals screening, DPPH free radical scavenging and xanthine oxidase inhibitiory activities of Cassia fistula seeds extract," Journal of Medicinal Plants Research, vol. 5, no. 10, pp. 1941-1947, 2011.

[30] H.-B. Li, C.-C. Wong, K.-W. Cheng, and F. Chen, "Antioxidant properties in vitro and total phenolic contents in methanol extracts from medicinal plants," LWT-Food Science and Technology, vol. 41, no. 3, pp. 385-390, 2008.

[31] G. S. Chakraborthy, "Free radical scavenging activity of Costus speciosus leaves," Indian Journal of Pharmaceutical Education and Research, vol. 43, no. 1, pp. 96-98, 2009.

[32] A. Yildirim, A. Mavi, and A. A. Kara, "Antioxidant and antimicrobial activities of Polygonum cognatum Meissn extracts," Journal of the Science of Food and Agriculture, vol. 83, no. 1, pp. 64-69, 2003.

[33] M. Zimmermann, "Ethical guidelines for investigations of experimental pain in conscious animals," Pain, vol. 16, no. 2, pp. 109-110, 1983.

[34] F. Yahya, S. S. Mamat, M. F. F. Kamarolzaman et al., "Hepatoprotective activity of methanolic extract of Bauhinia purpurea leaves against paracetamol-induced hepatic damage in rats," Evidence-Based Complementary and Alternative Medicine, vol. 2013, Article ID 636580, 10 pages, 2013.

[35] W. Y. Ho, S. K. Yeap, C. L. Ho, R. Abdul Rahim, and N. B. Alitheen, "Hepatoprotective activity of elephantopus scaber on alcohol-induced liver damage in mice," Evidence-Based Complementary and Alternative Medicine, vol. 2012, Article ID 417953, 8 pages, 2012.

[36] K. S. Rao and S. H. Mishra, "Studies on Curculigo orchioides Gaertn. for anti-inflammatory and hepatoprotective activities," Indian Drugs, vol. 33, no. 1, pp. 20-25, 1996.

[37] N. E. Mohamad, S. K. Yeap, K. L. Lim et al., "Antioxidant effects of pineapple vinegar in reversing of paracetamol-induced liver damage in mice," Chinese Medicine, vol. 10, article no. 3, 2015.

[38] R. Parul, S. Kumar, and P. Saha, "In Vitro nitric oxide scavenging activity of methanol extracts of three Bangladeshi medicinal 
plants," The Pharma Innovation Journal, vol. 1, no. 12, pp. 83-88, 2012.

[39] Y.-C. Chung, C.-T. Chang, W.-W. Chao, C.-F. Lin, and S.-T. Chou, "Antioxidative activity and safety of the 50\% ethanolic extract from red bean fermented by Bacillus subtilis IMR-NK1," Journal of Agricultural and Food Chemistry, vol. 50, no. 8, pp. 2454-2458, 2002.

[40] C. Girish, B. C. Koner, S. Jayanthi, K. R. Rao, B. Rajesh, and S. C. Pradhan, "Hepatoprotective activity of six polyherbal formulations in paracetamol induced liver toxicity in mice," Indian Journal of Medical Research, vol. 129, no. 5, pp. 569-578, 2009.

[41] Y.-L. Chew, J.-K. Goh, and Y.-Y. Lim, "Assessment of in vitro antioxidant capacity and polyphenolic composition of selected medicinal herbs from Leguminosae family in Peninsular Malaysia," Food Chemistry, vol. 116, no. 1, pp. 13-18, 2009.

[42] X. Gao, M. Ohlander, N. Jeppsson, L. Björk, and V. Trajkovski, "Changes in antioxidant effects and their relationship to phytonutrients in fruits of sea buckthorn (Hippophae rhamnoides L.) during maturation," Journal of Agricultural and Food Chemistry, vol. 48, no. 5, pp. 1485-1490, 2000.

[43] M. Kaneria, B. Kanani, and S. Chanda, "Assessment of effect of hydroalcoholic and decoction methods on extraction of antioxidants from selected Indian medicinal plants," Asian Pacific Journal of Tropical Biomedicine, vol. 2, no. 3, pp. 195-202, 2012.

[44] T. Osawa, "Novel natural antioxidants for utilization in food and biological systems," in Postharvest Biochemistry of Plant Food Materials in the Tropics, I. Utritani, V. V. Garcia, and E. M. Mendoza, Eds., pp. 241-251, Japan Scientific Societies Press, Tokyo, Japan, 1994.

[45] K. Shimada, K. Fujikawa, K. Yahara, and T. Nakamura, "Antioxidative properties of xanthan on the autoxidation of soybean oil in cyclodextrin emulsion," Journal of Agricultural and Food Chemistry, vol. 40, no. 6, pp. 945-948, 1992.

[46] L. R. Fukumoto and G. Mazza, "Assessing antioxidant and prooxidant activities of phenolic compounds," Journal of Agricultural and Food Chemistry, vol. 48, no. 8, pp. 3597-3604, 2000.

[47] A. U. Tatiya, A. K. Saluja, and S. J. Surana, "Antioxidant and analgesic activity of various fractions of bark of Machilus macrantha (Nees)," International Journal of Pharmacology and Biological Sciences, vol. 2, pp. 29-38, 2008.

[48] A. Turkoglu, M. E. Duru, N. Mercan, I. Kivrak, and K. Gezer, "Antioxidant and antimicrobial activities of Laetiporus sulphureus(Bull.) Murrill," Food Chemistry, vol. 101, no. 1, pp. 267-273, 2007.

[49] H. L. Madsen, C. M. Andersen, L. V. Jørgensen, and L. H. Skibsted, "Radical scavenging by dietary flavonoids. A kinetic study of antioxidant efficiencies," European Food Research and Technology, vol. 211, no. 4, pp. 240-246, 2000.

[50] S. C. Jagetia, M. S. Balgia, and K. Babu, "Evaluation of nitric oxide scavenging activity of certain herbal formulation in vitro," Phytotherapy Research, vol. 18, no. 7, pp. 561-565, 2004.

[51] A. Crozier, J. Burns, A. A. Aziz et al., "Antioxidant flavonols from fruits, vegetables and beverages: measurements and bioavailability," Biological Research, vol. 33, no. 2, pp. 79-88, 2000.

[52] A. Yıldırım, A. Mavi, M. Oktay, A. A. Kara, O. F. Algur, and V. Bilaloglu, "Comparison of antioxidant and antimicrobial activities of Tilia (Tilia argentea Desf ex DC), sage (Salvia triloba L.), and Black tea (Camellia sinensis) extracts," Journal of
Agricultural and Food Chemistry, vol. 48, no. 10, pp. 5030-5034, 2000.

[53] H. Mohamed, M. Ons, E.-T. Yosra, S. Rayda, G. Neji, and N. Moncef, "Chemical composition and antioxidant and radicalscavenging activities of Periploca laevigata root bark extracts," Journal of the Science of Food and Agriculture, vol. 89, no. 5, pp. 897-905, 2009.

[54] C. A. Rice-Evans, N. J. Miller, and G. Paganga, "Structureantioxidant activity relationships of flavonoids and phenolic acids," Free Radical Biology and Medicine, vol. 20, no. 7, pp. 933956, 1996.

[55] R. A. Saad, M. F. EL-Bab, and A. A. Shalaby, "Attenuation of acute and chronic liver injury by melatonin in rats," Journal of Taibah University for Science, vol. 7, no. 2, pp. 88-96, 2013.

[56] C. Latchoumycandane, Q. M. Seah, R. C. H. Tan, J. Sattabongkot, W. Beerheide, and U. A. Boelsterli, "Leflunomide or A77 1726 protect from acetaminophen-induced cell injury through inhibition of JNK-mediated mitochondrial permeability transition in immortalized human hepatocytes," Toxicology and Applied Pharmacology, vol. 217, no. 1, pp. 125-133, 2006.

[57] B. P. Pimple, P. V. Kadam, N. S. Badgujar, A. R. Bafna, and M. J. Patil, "Protective effect of Tamarindus indica Linn against paracetamol-induced hepatotoxicity in rats," Indian Journal of Pharmaceutical Sciences, vol. 69, no. 6, pp. 827-831, 2007.

[58] G. M. Rao, G. Rao, K. Ramnarayan, and K. K. Shrinivasan, "Effect of hepatoguard on paracetamol induced liver injury in male albino rats," Indian Drugs, vol. 30, no. 1, pp. 40-47, 1992.

[59] G. Tajua, M. Jayanthia, M. Nazeer bashab, K. Nathiga, and A. Sivaraj, "Hepatoprotective effect of Indian medicinal plant Psidium Guajava Linn. Leaf extract on paracetamol induced liver toxicity in Albino rats," Journal of Pharmacy Research, vol. 3, no. 8, pp. 1759-1763, 2010.

[60] D. J. Jollow, J. R. Mitchell, W. Z. Potter, D. C. Davis, J. R. Gillette, and B. B. Brodie, "Acetaminophen induced hepatic necrosis. II. Role of covalent binding in vivo," Journal of Pharmacology and Experimental Therapeutics, vol. 187, no. 1, pp. 195-202, 1973.

[61] D. E. Amacher, "A toxicologist's guide to biomarkers of hepatic response," Human and Experimental Toxicology, vol. 21, no. 5, pp. 253-262, 2002.

[62] R. A. Nathwani, S. Pais, T. B. Reynolds, and N. Kaplowitz, "Serum alanine aminotransferase in skeletal muscle diseases," Hepatology, vol. 41, no. 2, pp. 380-382, 2005.

[63] M. I. Thabrew, P. D. T. M. Joice, and W. Rajatissa, "A comparative study of the efficacy of Pavetta indica and Osbeckia octandra in the treatment of liver dysfunction," Planta Medica, vol. 53, no. 3, pp. 239-241, 1987.

[64] M. P. Holt, L. Cheng, and C. Ju, "Identification and characterization of infiltrating macrophages in acetaminophen-induced liver injury," Journal of Leukocyte Biology, vol. 84, no. 6, pp. 14101421, 2008.

[65] M. B. Obogwu, A. J. Akindele, and O. O. Adeyemi, "Hepatoprotective and in vivo antioxidant activities of the hydroethanolic leaf extract of Mucuna pruriens (Fabaceae) in antitubercular drugs and alcohol models," Chinese Journal of Natural Medicines, vol. 12, no. 4, pp. 273-283, 2014.

[66] S. Gaweł, M. Wardas, E. Niedworok, and P. Wardas, "Malondialdehyde (MDA) as a lipid peroxidation marker," Wiadomosci lekarskie, vol. 57, no. 9-10, pp. 453-455, 2004.

[67] H. Jaeschke, T. R. Knight, and M. L. Bajt, "The role of oxidant stress and reactive nitrogen species in acetaminophen hepatotoxicity," Toxicology Letters, vol. 144, no. 3, pp. 279-288, 2003. 
[68] V. Sumathy, Z. Zuraini, and S. Sasidharan, "In vivo toxicity study of Cassia surattensis flower extract," Research Journal of Pharmaceutical, Biological and Chemical Sciences, vol. 2, no. 3, pp. 607-617, 2011.

[69] OECD, Guidelines for the Testing of Chemicals. Revised Draft Guideline: Acute Oral Toxicity, Organization for Economic Cooperation and Development, Paris, France, 2001.

[70] C. K. Roy, J. V. Kamath, and M. Asad, "Hepatoprotective activity of Psidium guajava Linn. leaf extract," Indian Journal of Experimental Biology, vol. 44, no. 4, pp. 305-311, 2006. 


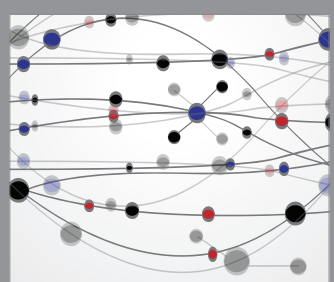

The Scientific World Journal
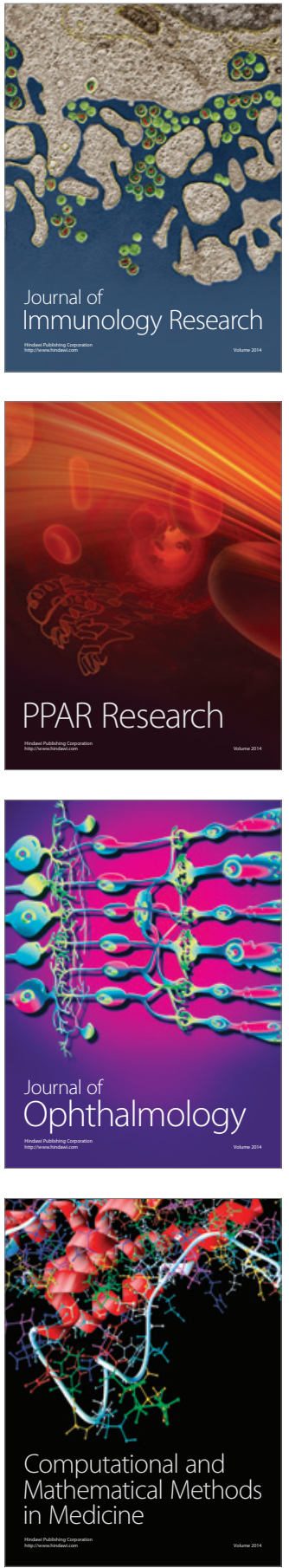

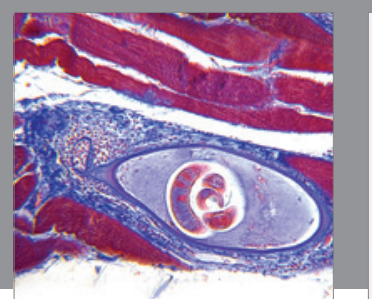

Gastroenterology Research and Practice

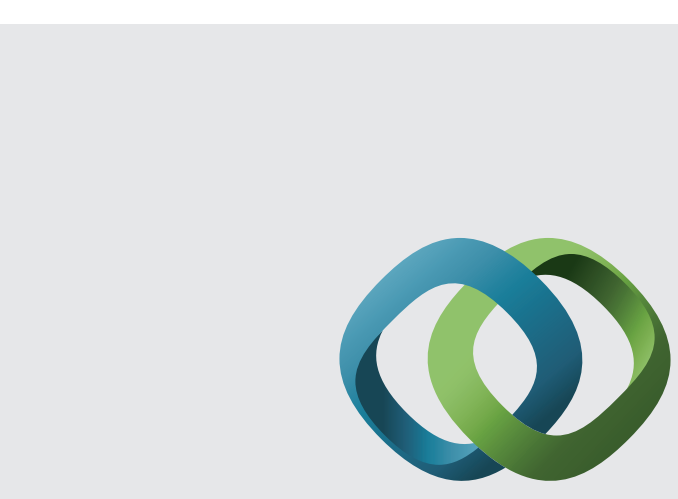

\section{Hindawi}

Submit your manuscripts at

http://www.hindawi.com
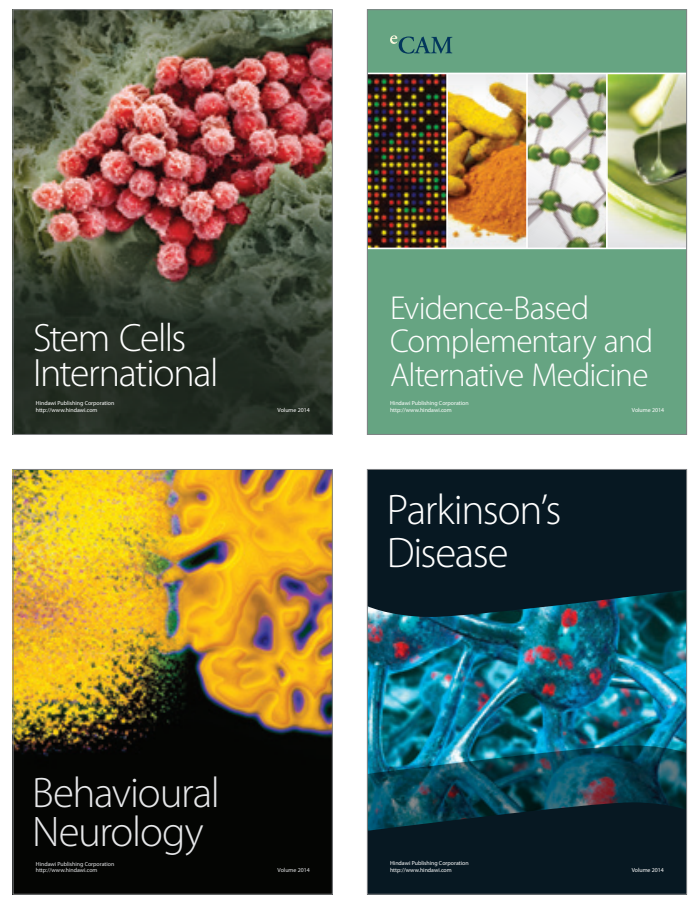
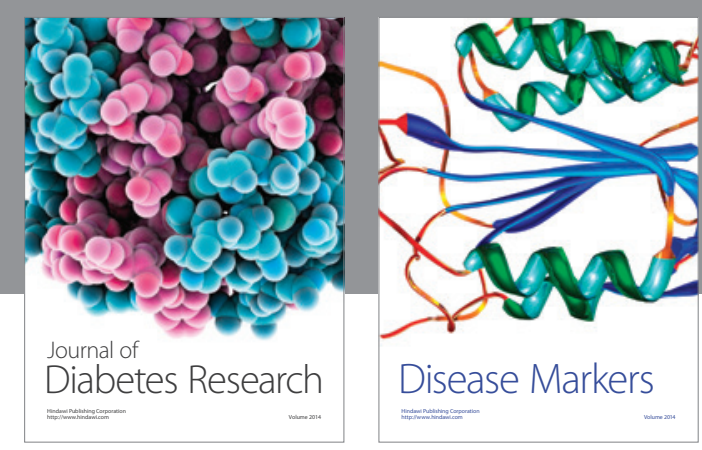

Disease Markers
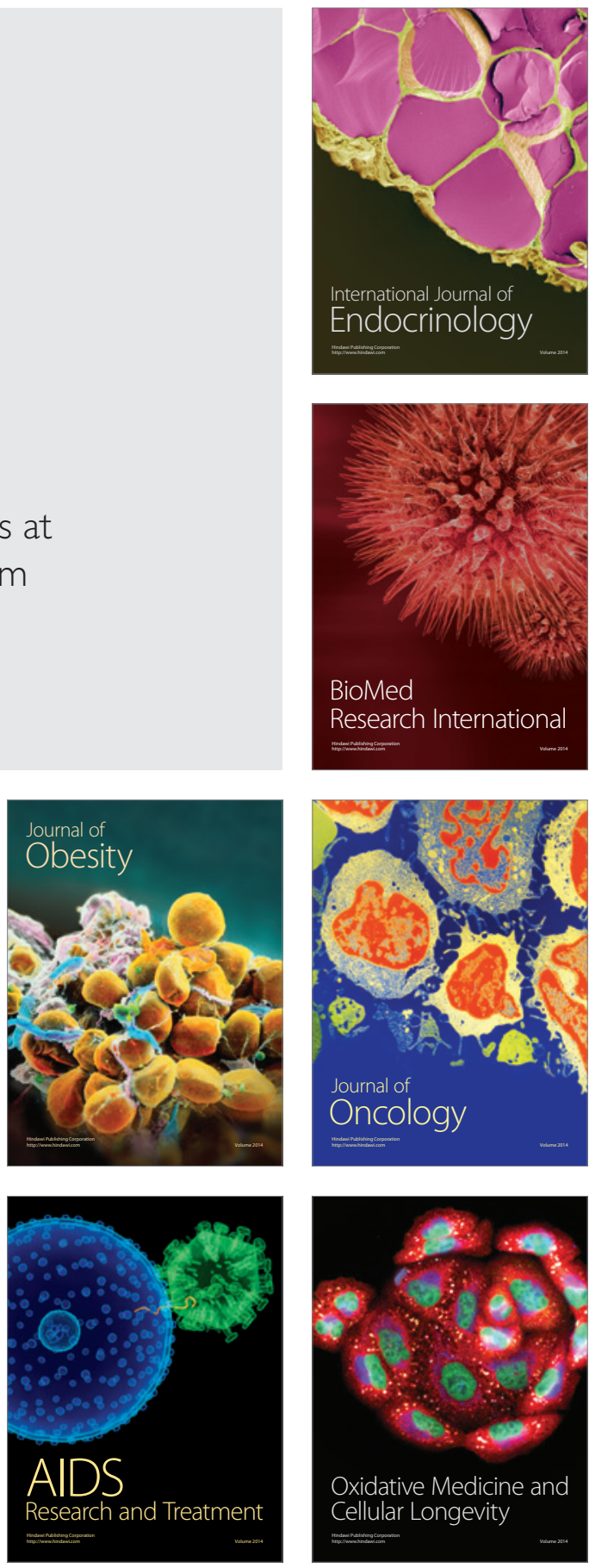